\title{
Origin, Traject and Distribution of Renal Arteries (Arteriae renalis) in Chinchilla lanigera
}

\author{
Cristian MARTONOS ${ }^{1}$, Cristian DEZDROBITU ${ }^{1}$, Florin STAN $^{1 *}$, Aurel DAMIAN ${ }^{1}$, Alexandru GUDEA ${ }^{1}$ \\ ${ }^{1}$ University of Agricultural Sciences and Veterinarian Medicine, Cluj-Napoca, Romania. \\ *corresponding author: florin.stan@usamvcluj.ro
}

Bulletin UASVM Veterinary Medicine 75(1)/2018

Print ISSN 1843-5270; Electronic ISSN 1843-5378

doi:10.15835/buasvmcn-vm:002517

\begin{abstract}
For the present study a number of 5 female chinchilla carcasses were used. The animals were slaughtered for commercial purpuses (fur). The anatomical dissection started with the identification of the aorta (Aorta abdominalis). The next step was the intra-arterial injection of a colouring substance. The carcasses was fixed in the formaldehyde solution and subsequently the renal arteries were dissected. The first renal artery was the right renal artery (Arteria renalis dextra) and, at 0,5 cm caudally, the left renal artery (Arteria renalis sinister) arose. The origin of those arteries were disposed on the lateral part of the abdominal aorta.

The origin, traject and distribution of renal arteries on the studied species have a high degree of similarity with the literature dates described for leporids.
\end{abstract}

Keywords: Anatomy, chinchilla, kidney, renal arteries.

\section{Introduction}

Part of Mammalia class, THERIA subclass, Eutheria group, Rodenția order, Hystricomorpha suborder, Chinchilidae family, Chinchilla species, this smalls rodents are very popular lately as pets.

Our study attempts to describe the origin, traject and macroscopically visible distribution of the renal arteries in Chinchilla lanigera, and the obtained results were compared with data reported in other species.

\section{Materials and methods}

The biological material originates from a private farm from Bistrița County (Romania) and is represented by five female chinchilla carcasses. After the intraabdominal approach, intra-arterial lavage with heparinised serum was performed and then injected $\mathrm{a}$ in the descending abdominal aorta (Aorta abdominalis) with $30 \mathrm{ml}$ of acrylic/ latex coloring agent. After a 5 days fixation period in $5 \%$ formaldehyde solution, the carcasses were dissected and the observed aspects were photographed and described.

\section{Results and discussions}

After the stratigraphic dissection we observed that in chinchilla, the renal arterie's (A.renalis) origins are found on the left and right side of the abdominal aorta, caudally to the cranial mesenteric artery (A. mesenterica cranialis).

In contrast with the chinchilla, the literature reports different aspects in rats (Moffat and Fourman, 1963; Yoldas et al., 2014) and Wistar mouse species (Nur and Yaldş, 2011), where the right renal artery arises from abdominal aorta, cranially to the origin of cranial mesenteric artery.

In Chinchilla lanigera, the first renal branch is represented by the right renal artery (A.renalis dextra), while the left renal artery's origin (A.renalis sinistra) is situated at 0,5 centimeters caudally from the first branch. Similar aspects were reported in literature in rabbit (Maženský et 
al., 2012), wolf (Özudogru and Özdemir, 2005) and Kangal dog (Özdemir et al., 2009).

Unlike our species, in guinea pig Shively and Stump, 1986 confirmed the presence of two right renal arteries in case of $50 \%$ of studied individuals.

From their origin, on the lateral part of abdominal aorta, these two renal arteries follow an medio-lateral traject on the ventral surface of the psoas muscle (Mm. psoas) and approach the kidneys at the level of the renal hilus (hilus renalis). The adrenal arteries (Aa. adrenales (Fig.1) arise as collateral branches.

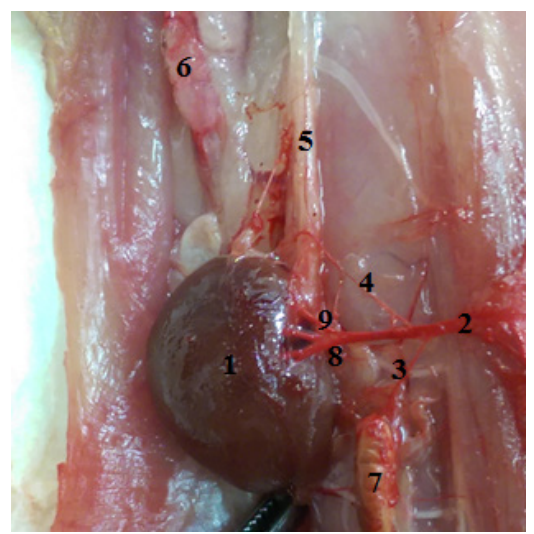

Figure 1. Distribution branches of the left renal artery 1-Left Kidney, 2-Left renal artery, 3- Left adrenal artery, 4- Left ureteric artery, 5- Left Ureter, 6- Left uterine horn, 7- Left adrenal gland, 8- Ventral renal branch, 9-Dorsal renal branch.

Other collateral branches are represented by the ureteric arteries, (left and right), (Ramus uretericus), detached from the renal arteries before those entering the renal hilus. These branches follow a latero-caudal trajectory and orientates towards the initial segment of the ureters (Fig.1). Same aspects were reported in rabbit where the initial part of the ureter is supplied by arterial branches which originate in the renal arteries (Douglas and Hossler, 1995). In chinchilla females, the right ovarian artery (A.ovarica dextra) is a collateral branch of right renal artery. Before approaching the renal hilus, each renal artery gives off a dorsal and a ventral renal branch which enter the kidney at the hilus area.

\section{Conclusions}

As far as origin, traject and distribution of renal arteries in studied species, one can conclude that we have a high degree of similarity with the reported data in literature concerning leporids.

In cranio-caudal direction the right renal artery is the first visceral branch after cranial mesenteric artery and the left renal artery detaches the at 0,5 $\mathrm{cm}$ caudally from the right renal artery. The renal arteries are individual branches which originate on the lateral walls of the abdominal aorta.

Acknowledgments. This research did not receive any specific grant from funding agencies in the public, commercial, or not-for-profit sectors.

\section{References}

1. Douglas CG, Hossler EF (1995). Vascular anatomy of the rabbit ureter. The Anatomical Record, 242: 47-56.

2. Maženský D, Purzyc H, Danko J (2012). Variations in the vascular anatomy of the rabbit kidney and its experimental significance. Acta Sci Pol, Medicina Veterinaria, 11: 25-34.

3. Moffat DB, Fourman J (1963). The vascular pattern of the rat kidney. J Anat, Lond, 97: 543-553.

4. Nur IH, Yaldaş A (2011). The brances variation of the renal artery in a wistar rat. J Fac Vet Med Univ Erciyes, 8: 211-216.

5. Özdemir D, Özüdoğru Z, Malkoç İ (2009). Intrarenal segmentation of the renal arteries in the kangal dog. Kafkas Üniv Vet Fak Derg, 15: 41-44.

6. Özudogru Z, Ozdemir D (2005). Intrarenal arterial patterns in the wolf (Canis Lupis). Vet Med - Czech, 50: 411-414.

7. Shively JM, Stump EJ (1986). The systemic arterial pattern of the guinea pig: the abdomen. Anat Rec, 185: 155-166.

8. Yoldas A, Aydin A, Ilgun R (2014). Macriscopic distribution of the renal artery and intrarenal arteries in moles rats (Spalax leucodon). Veterinarni Medicina, 59: 382-387. 